\title{
Renato Tapajós, há 50 anos - prisão, tortura e escrita: notas em torno do autor e do livro Em câmara lenta.
}

\author{
Renato Tapajós, 50 years ago - arrestment, torture and writing: notes on Brazilian \\ author and his book Em câmara lenta. \\ Carlos Augusto Carneiro COSTA* \\ Universidade Federal do Sul e Sudeste do Pará (UNIFESSPA)
}

\begin{abstract}
RESUMO: Há pouco mais de 40 anos (1979), a segunda edição do romance Em câmara lenta era publicada, após um longo processo envolvendo a censura do livro, publicado pela primeira vez em 1977, e a prisão do seu autor, acusado de construir "ataques e calúnias aos Governos [militares]", por meio de uma obra "disfarçada por uma casca literária". Um parecer de Antonio Candido explicitou suas qualidades estéticas e concluiu que "não é um livro subversivo". Partindo destas questões, o presente estudo propõe um exame da militância política desse escritor e cineasta paraense, preso e diversas vezes torturado há pouco mais de 50 anos (1969), e uma análise do romance, pontualmente o episódio de prisão e tortura da personagem Ela, núcleo de toda a trama da narrativa. Em tempos sombrios, como os de hoje, a fantasmagoria do terror se faz ainda mais perturbadora, exigindo redobramento do estado de alerta. Por essa razão, insistir na leitura deste romance parece ser tarefa urgente e permanente para a crítica literária.
\end{abstract}

PALAVRAS-CHAVE: Militância política. Prisão. Tortura.

ABSTRACT: Just over forty years ago (1979), the second edition of the novel Em câmara lanta was published, after a long process involving the prohibition of the book, first published in 1977, and its author's arrestment, accused of provoking "attacks and slander against Governments [militaries]", through a book "disguised by a literary mask". A document emitted by Antonio Candido explained its aesthetic qualities and concluded that "it is not a subversive book". Through these questions, the present study proposes an examination of political activism of that Brazilian

\footnotetext{
* Doutor em Letras: Estudos Literários (Área: Teoria da Literatura e Literatura Comparada) pela Universidade Federal de Minas Gerais (UFMG). Mestre em Literatura Brasileira pela Universidade de São Paulo (USP). Professor de Estudos Literários da Universidade Federal do Sul e Sudeste do Pará (UNIFESSPA), lotado no Instituto de Estudos do Xingu (IEX), Campus de São Félix do Xingu. E-mail: cac@unifesspa.edu.br.
} 
writer and filmmaker, arrested and several times tortured just over fifty years ago (1969), and an analysis of the novel, principally the episode of arrestment and torture of the character Ela, core of the narrative plot. In dark times, like today, the Phantasmagoria of terror turns even more frightening, requiring redoubled alertness. For this reason, the insistence on reading this novel seems to be an urgent and permanent task for the literary criticism.

KEYWORDS: Political militancy. Arrestment. Torture.

\section{Introdução}

É muito difícil ler uma obra literária sem pensar nas possibilidades de envolvimento pessoal do escritor na história contada, sobretudo no tocante a produções auto ficcionais e testemunhais. Boa parcela da produção inserida principalmente no contexto das últimas décadas do século XIX, atravessando praticamente todo o século $\mathrm{XX}$, guarda a singularidade de haver sido construída a partir de determinações da experiência pessoal geralmente ligadas tanto às experiências catastróficas das duas grandes guerras planetárias, quanto à aniquilação do sujeito e das relações sociais, provocada pelos rearranjos ultrajantes do capitalismo. Em geral, isso ocorre com autores cuja subjetividade tenha sido de algum modo afetada por atos de violência. Consciente ou não desses fatos, o leitor quase sempre constrói expectativas de reconhecer, nos interstícios da obra, elementos ligados à vida pessoal do artista, seja por meio de uma narrativa que opta pela explicitação direta de atos de violência, seja por meio de uma narrativa que estetiza a violência a partir do relato, dando ênfase à representação de seus efeitos psíquicos. Recordações da casa dos mortos (1862), de Dostoievski, É isto um homem? (1947), de Primo Levi, e Memórias do cárcere (1953), de Graciliano Ramos, são exemplos clássicos de obras literárias marcadas pelo relato de experiências dolorosas dos seus respectivos escritores.

No romance Em câmara lenta ${ }^{2}$, a conjugação entre vida e obra de Renato Tapajós se apresenta de modo bastante perturbador, na medida em que dados autobiográficos se entrecruzam com procedimentos narrativos com elevado grau de elaboração ficcional,

\footnotetext{
${ }^{2}$ A primeira edição do romance, como dito, é de 1977. O presente estudo utiliza a segunda edição, de 1979. 
provocando indeterminações que dificultam a apreensão clara e objetiva da história contada.

Assim, no dia 31 de agosto de 1969, Renato Carvalho Tapajós se tornava mais uma entre centenas de pessoas presas e torturadas pela polícia militar por conta de sua militância contra a ditadura. Na época, o jovem estudante de Sociologia, nascido em Belém do Pará e radicado em São Paulo desde os dezenove anos, já exercia a profissão de cineasta, tendo realizado seus primeiros trabalhos na linha do documentário: Universidade em crise (1966), Um por cento (1967) e Vila da Barca (1968), ganhador do prêmio de melhor filme no Festival Internacional do Filme de Leipzig, Alemanha. Essas produções corresponderam aos sintomas iniciais de um espírito contestador que não se limitaria ao campo político, mas ao da produção cultural também.

Cinco anos depois de sua prisão, em setembro de 1974, Renato era posto em liberdade. Entre os poucos objetos pessoais que carregava na mala, havia um bloco de papel de jornal no qual passava a limpo tudo o que antes escrevia em pequenos pedaços de papel-manteiga usado para proteger os cigarros dentro da carteira. Três anos mais tarde, em 1977, numa tiragem de três mil exemplares, Renato publicava o romance Em câmara lenta, misto de relato autoficcional com elementos próprios da narrativa de testemunho em torno da tentativa de compreensão dos eventos que culminam com a tortura e morte da personagem Ela, cuja caracterização é, na perspectiva da matéria de extração histórica (BASTOS, 2000) aproveitada no romance, figuração textual da cunhada do próprio autor à época de sua prisão em razão da atuação política, a jovem estudante de Psicologia da Universidade de São Paulo, Maria Aurora Nascimento Furtado.

Quinze dias após a noite de lançamento do livro, Tapajós era novamente preso. De acordo com o relatório de análise feito pelo DOI/CODI, o romance apresentava conteúdo de apologia à subversão, com incitação à guerra revolucionária e ataques e calúnias ao governo. Por essas razões, o livro foi proibido de circular. Depois de aproximadamente um mês detido, parte dele em regime de incomunicabilidade, Renato foi solto e passou a responder o processo em liberdade. Dentre os principais instrumentos utilizados pelo advogado Aldo Lins e Silva em sua defesa, figura um importante parecer escrito por Antonio Candido (publicado nos anexos da dissertação de mestrado defendida em 2006 na Unicamp, intitulada Prelúdios \& Noturnos: ficções, revisões e trajetórias de 
um projeto político, de Mário Augusto Medeiros da Silva) que ressalta as qualidades literárias do romance e defende seu caráter estritamente ficcional. Em 1979, Em câmara lenta tem sua segunda edição publicada, mas, desta vez, sem os impedimentos da censura.

A atuação política de Renato Tapajós antes e durante os anos de autoritarismo militar suscita reflexões não apenas sobre o papel da resistência à Ditadura, mas, também, sobre a configuração estética da arte de resistência (BOSI, 2002) e, no caso específico, a literatura. Por isso, parece importante refletir sobre seu engajamento, o sentido e a importância de sua obra para a produção cultural brasileira contemporânea.

\section{Renato Tapajós na vida e na ficção}

Em câmara lenta possui três momentos em que o leitor é levado a conhecer os primeiros anos de militância do narrador, quando este ainda era estudante secundarista em Belém-PA. A segunda vez em que a lembrança desta fase é evocada, a atenção se volta para a revelação da ingenuidade do narrador em relação ao Comunismo e ao seu significado, ao mesmo tempo em que é revelado o modo como passou a se identificar com os problemas sociais ao seu redor: "Aquelas ideias haviam se tornado reais, mas estavam todas desarrumadas, desarticuladas, caóticas. Levei muito tempo tentando arrumá-las, mergulhando na vida para colocá-las em ordem. E descobri que sua ordem é a própria vida" (TAPAJÓS, 1979, p. 72).

Neste trecho é interessante notar que a desorganização do pensamento do narrador em seus primeiros contatos com ideias de revolução é semelhante ao processo de construção da narrativa, caracterizado por indeterminações e fragmentos descontínuos. Essa situação possui vínculos com o movimento estruturante do romance, que incorpora formalmente as contradições presentes no discurso do narrador (ROSENFELD, 1973).

Em entrevista, Tapajós afirma que a leitura de obras literárias era uma das maiores ocupações de sua infância. Ficava grande parte do dia trancado em uma biblioteca da casa onde morava, em Belém: “[...] Eu inclusive aprendi a ler antes de ir pra escola. Com quatro ou cinco anos eu já sabia ler. Meu pai tinha uma biblioteca gigantesca [...]. Então eu comecei a ler muito cedo" (COSTA, 2009, p. 129). Em algumas passagens do romance, essa informação se cruza com a fala do narrador, principalmente quando este admite que os livros representaram seu instrumento de inserção mais afirmativo na vida social. 
A situação de clandestinidade do narrador também encontra ressonância na militância de Tapajós, que permaneceu escondido até ser preso. No romance, o narrador se encontra em situação análoga a de autoexílio dentro de uma casa, a espera de notícias sobre a personagem Ela. É deste lugar que a voz narrativa se lança em lembranças de momentos de tensão, como ações armadas, e de momentos íntimos com a personagem feminina. Essa experiência clandestina dentro do próprio país sugere uma determinada condição de aprisionamento. Sair da casa oferece risco de morte, ou ao menos de prisão. Permanecer dentro é ainda mais agressivo, uma vez que lá o narrador não consegue se esquivar da convivência com imagens dolorosas de seus companheiros mortos:

\footnotetext{
O vazio, outra vez, como agora, sozinho em casa, sentado na beira da cama, olhando a parede. Quase escuridão, um zumbido surdo, a pele se esticando, os olhos mortos cansados de ver e vendo, ainda uma vez, na parede o rosto dela, os cabelos curtos, os olhos ligeiramente estrábicos dando um ar de distanciamento no rosto branco, como se visse o mundo de longe, com segurança e certeza do que via. O rosto multiplicado assumindo outras formas, outros rostos, todos mortos (TAPAJÓS, 1979, p. 24).
}

Se se pode afirmar, por um lado, que o ambiente carregado de imagens fantasmagóricas dos companheiros constitui uma demanda excessiva de sofrimento para o narrador, o que poderia lhe motivar a abandonar a causa, por outro lado, também é possível dizer que a convivência com essas imagens estimula a atitude resistência. Os objetos descritos na casa são apresentados como se estivessem em situação de confronto com o narrador, e parecem incorporar a imagem do próprio torturador. A entrevista com Tapajós mostra que, em uma real condição de prisioneiro, o torturador tem forma monstruosamente palpável e age não apenas sobre o corpo, mas principalmente sobre a estrutura psíquica:

Pau-de-arara, e no pau-de-arara, você pendurado no pau-de-arara, você sofria espancamento, choque elétrico, afogamento, tudo combinado com o pau-dearara. Aí tinha a cadeira-do-dragão, que era a cadeira de choque. E, além disso, fuzilamentos simulados, atropelamentos simulados, espancamento indiscriminado dentro da cela. Quer dizer, é um clima de completo terror e de destruição física, mesmo. A gente saía de lá completamente arrebentado do ponto de vista físico [...]. E o psicológico também. É um negócio que varia 
muito. É meio difícil definir como é que foi pra mim essa coisa psicológica. Só posso te dizer o seguinte: quando eu saí da cadeia, que eu voltei a fazer cinema, eu levei praticamente nove anos pra conseguir voltar ao tema da militância política (COSTA, 2009, p. 135).

A cena de tortura apresentada no romance é análoga à relatada por Tapajós na entrevista, em que os algozes se valem de semelhantes instrumentos usados para torturálo, com a adição da coroa-de-cristo (no caso da ficção), que esmaga o crânio à medida que parafusos fixados em torno do círculo de metal são enroscados. Trata-se da cena de tortura da personagem Ela, que será analisada na segunda parte deste estudo. Por hora, importa dizer que o caso relatado no romance tem origem em uma experiência bastante traumática para Tapajós. Na entrevista, ele conta que em 1972, Aurora Maria Nascimento Furtado, irmã de sua então esposa, foi presa, torturada e morta por policiais militares, depois de uma abordagem. A personagem Ela teria sido construída, segundo ele, com base em sua cunhada, assim como vários outros companheiros seus tiveram suas histórias ficcionalizadas no romance. Quando questionado se havia perdido alguma pessoa afetivamente ligada a ele, o escritor responde da seguinte maneira:

\footnotetext{
Ah, sim, sem dúvida alguma [pausa longa]. A minha cunhada. A pessoa mais próxima que eu perdi foi a minha cunhada, a Lola. A Aurora Maria Nascimento Furtado. Era irmã da então minha mulher, da Laís. E era u-ma pessoa com quem eu tinha uma proximidade muito grande. Era muito amigo dela. E ela foi assassinada de uma maneira absolutamente brutal. É o assassinato que eu descrevo no Em câmara lenta (COSTA, 2009, p. 137).
}

Esse evento, associado às torturas sofridas por Tapajós na prisão e à desilusão quanto à tentativa de derrubar a ditadura, deixou o escritor bastante abatido e, por algum tempo, impossibilitado de falar a respeito: "Eu havia escrito o Em câmara lenta na cadeia, publiquei o livro, fui preso novamente por causa do livro, mas fora da cadeia eu praticamente não escrevi, nem filmei, nem fiz nada durante todo o resto da década de 70 " (COSTA, 2009, p. 136). Tapajós também comenta sobre o significado e a necessidade da luta armada durante os chamados "anos de chumbo", ressaltando sua validade enquanto meio legítimo de combate em uma situação de extrema opressão: “Olha, eu era totalmente fechado com a ideia da luta armada. Quer dizer, a única maneira de realizar as 
transformações necessárias - derrubar a ditadura, construir o socialismo - só poderiam ser feitos através da luta armada [...]" (p. 138).

A convicção do escritor dialoga com a expectativa que o narrador constrói no romance em relação à resistência diante do inimigo. A situação de confronto é diversas vezes reiterada ao longo da narrativa, de modo que o narrador demonstra comportar-se em constante estado de alerta. Interessa notar que este estado funciona como mecanismo legítimo de autopreservação. Contudo, muitas atitudes que este narrador toma ao longo da história apontam para uma completa exposição do corpo à ameaça de morte, como o ato de confrontar sozinho vários policiais fortemente armados.

Reflexões metanarrativas também fazem parte da estratégia narrativa do romance de Tapajós. Elas surgem especificamente quando o narrador se refere às dificuldades que tem de pensar, seja pela interferência de fatores externos: "Não é possível pensar direito com esse ruído surdo que bate nos ouvidos" (TAPAJÓS, 1979, p. 48), seja pela percepção da impossibilidade de continuar escrevendo sobre o evento que, de tão insuportável, se torna difícil de compreender. Não se trata somente de uma reflexão sobre a dificuldade de entender o evento traumático, mas também de uma discussão em torno dos limites da linguagem diante de uma situação profundamente impactante do ponto de vista da violência: “O jogo de armar [grifo nosso] está aí, para quem puder entendê-lo e encaixar todas as peças. Eu não posso mais - nenhuma coerência quando se destroem algumas peças: ela e a confiança" (p. 87). A expressão grifada remete à fragmentação do romance (BENJAMIN, 1984), assim como alude à maneira dispersiva como as lembranças estão organizadas na memória do narrador.

Segundo Tapajós, a ideia de transformar Em câmara lenta em romance foi posterior ao início da escrita. Explica que depois de algumas páginas concluídas sob o impacto das emoções que sentia dentro da prisão em relação a tudo o que havia acontecido com sua organização, percebeu que poderia dar forma de romance ao texto:

[...] quando eu comecei a escrever o romance eu não estava nem pensando em escrever o romance, eu estava com um monte de sensações, sentimentos etc. engasgados na garganta [...]. Depois de eu ter começado a escrever, ele foi começando a tomar forma de romance, até eu tomar consciência de que aquilo era um romance, e aí eu comecei a escrever como tal. Mas comecei a escrever 
como um jogo de liberação das emoções que estavam rolando (COSTA, 2009, p. 143).

As circunstâncias de produção do romance também chamam a atenção por seu ineditismo dentro da literatura brasileira do século XX. Tapajós conta que, enquanto estava preso, escrevia em pedaços de papel-manteiga, com letras muito pequenas. Depois, por segurança, copiava o conteúdo em papel-jornal e escondia dentro da cela. Seus pais, quando iam visitá-lo, levavam para casa a versão escrita em papel-manteiga e transcreviam com a ajuda de uma lupa e uma máquina de datilografar.

O mais importante a ser ressaltado aqui é o modo como esses originais eram transportados. Tapajós dobrava as pequenas folhas de papel-manteiga e as embrulhava com fita gomada (durex), de modo que se tornavam impermeáveis e ganhavam o formato de uma cápsula de medicamento. A mãe do escritor colocava os pequenos embrulhos embaixo da língua e saía sem levantar suspeitas, uma vez que a revista só era realizada durante a entrada dos visitantes.

Associado àquela inicial despretensão de Tapajós em produzir um romance, as circunstâncias sob as quais Em câmara lenta foi escrito também permitem crer que sua fragmentação e dispersão encontram ressonância em elementos que vão além da situação de perda ficcionalizada na narrativa, ou do simples fato de que a história obedece a critérios de composição caros ao romance moderno. A forma de Em câmara lenta pode ter sido bastante determinada pela maneira como o livro saiu da prisão. É decomposto para, posteriormente, ser composto, ou destruído para ser construído (CORTÁZAR, 2007). A extraordinária manipulação dos fragmentos escritos em papel-manteiga possui uma imagem extremamente perturbadora, pois dá uma ideia das condições precárias de sobrevivência de Tapajós.

O contexto político brasileiro da década de 70 também exerce profundo impacto sobre essa produção. A ditadura militar de 1964, caracterizada pelo autoritarismo e suas consequentes práticas de violência que provocaram desordem nas relações entre indivíduos de muitos setores sociais e instituições repressoras do Estado, organizou o modo de vida social, por meio da proibição da liberdade de expressão, cassação de mandatos políticos, censura dos meios de comunicação, tortura e assassinato de opositores ao regime, e diversas outras formas de opressão. 
Em câmara lenta foi produzido nesse momento. Tapajós pode ser considerado um sobrevivente por tudo o que passou dentro da prisão. Seu engajamento se faz notar tanto na arte quanto na militância política. É nesse sentido que para Marcelo Ridenti (2010), boa parte das obras de arte produzidas a partir do final dos anos 50 constituiu-se pelo que denomina "estrutura de sentimento". Havia, segundo ele, um "sentimento de pertença" que unia artistas e intelectuais de esquerda em torno de um ideal revolucionário contrário às determinações dos militares. Precisamente, o autor define esse movimento como "estrutura de sentimento da brasilidade (romântico) revolucionária" (2010, p. 87). Essa tese dialoga com outra exposta em um de seus trabalhos anteriores, em que o autor defende a existência de um romantismo revolucionário como característica fundamental da produção artística dos anos 60 e início dos anos 70 (RIDENTI, 2000). Havia, neste caso, uma vontade de transformação da sociedade, a partir da construção de um homem novo, que seria encontrado em sua forma mais primitiva de convivência social.

No romance de Tapajós é possível encontrar ecos dessa especificidade de romantismo. Trata-se de um movimento contraditório dentro de sua própria estrutura, em que o sentimento de frustração pela impossibilidade de derrubar a ditadura alterna com indicações de que uma geração futura dará conta do processo revolucionário: "Porque nós, os já marcados, os comprometidos, não podemos mais. Eu não posso mais" (TAPAJÓS, 1979, p. 152). Esse lamento contrapõe-se à afirmação da resistência, por mais que tenha sido aniquilada. O narrador define-se como "sobrevivente de um exército derrotado e vitorioso porque nossa derrota mostrará o caminho e esse caminho conduzirá os outros e então o inimigo será destruído" (p. 174).

Uma visão um pouco mais ampla sobre o engajamento de Tapajós contra o autoritarismo militar pode se dar por uma abordagem sumária sobre sua atuação na Ala Vermelha do PCdoB (Partido Comunista do Brasil), a partir da visão de um historiador politicamente comprometido com a luta contra o regime, e que observou de perto os desdobramentos do conflito entre militares e a oposição.

Em seu livro Combate nas trevas, Jacob Gorender (1990) analisa o percurso revolucionário desenvolvido pela esquerda brasileira, que se inicia com as ilusões quanto à possibilidade de transformação da sociedade, e culmina com o processo de guerrilha urbana e rural. Durante a ditadura, várias decisões do governo tornaram difícil a permanência, no Brasil, de alguns intelectuais, estudantes e políticos. Uma das soluções 
imediatas foi o autoexílio. Entretanto, houve quem permanecesse no país, ainda que de modo clandestino, pois já não era possível qualquer forma de manifestação pública de repúdio ao regime. Houve também quem preferisse simplesmente silenciar-se. Mas este silêncio não se vinculou apenas ao medo. Muitos o preferiram, dada a necessidade de permanecer vivos, quando o heroísmo se fazia inútil.

Segundo Gorender (1990, p. 79), dentro da própria esquerda brasileira "prevalece a tendência à fragmentação". Os vários "rachas" surgidos dentro dos partidos políticos logo após as primeiras derrotas sofridas pela esquerda são os indícios de que as formas de resistência à ditadura não poderiam caminhar em um sentido coeso, como se as organizações pensassem em um plano comum de desmantelamento do Estado ditatorial. A decisão pela luta armada, bem como seu modo de construção, seguiu orientação intelectual dos principais líderes revolucionários que àquela altura já haviam encampado resistência em outros países da América Latina.

Principal mecanismo de luta armada, o foquismo é considerado como o grande trunfo da Revolução Cubana. Sua dinâmica de funcionamento corresponde à formação inicial de um pequeno grupo de guerrilheiros que se concentra em regiões preferencialmente montanhosas, de onde empreende resistência. Objetivamente, de acordo com Gorender, Ernesto Che Guevara, líder revolucionário e criador da teoria do foco, acreditava na existência de condições favoráveis à luta. Para o historiador, a expectativa quanto à construção de um foco de guerrilha por um resumido número de atores, em uma região camponesa, era a de que produzisse efeito na consciência da massa. Esperava-se que o povo desenvolvesse empatia com os guerrilheiros envolvidos e entrasse decisivamente no processo revolucionário.

Em câmara lenta apresenta algumas passagens estruturadas a partir de reflexões do narrador que dialogam com a referida teoria. O romance faz uma alusão direta à atuação guerrilheira do líder da Revolução Cubana. Referindo-se à opção da personagem Venezuelano de participar da construção de focos de guerrilha no Brasil, o narrador diz: "Ele sabia vagamente que o próprio Guevara estava indo para lá [Bolívia]" (TAPAJÓS, 1979, pp. 20-21). Essa passagem sugere que Renato Tapajós, ao escrever o romance, era conhecedor da teoria do foco. Ele também foi capaz de perceber e reconhecer no romance o fracasso das organizações de esquerda. Uma das autocríticas que faz, por meio de seu narrador, diz respeito à ineficiência da guerrilha urbana e, principalmente, à incapacidade 
que tinha a organização de conquistar a simpatia do povo. As reflexões do narrador são construídas em torno de indagações: "Afinal porque falhamos? Porque diminuímos de número a cada dia, porque ninguém respondeu ao nosso chamado, porque não conseguimos ir para o campo, porque as organizações foram destruídas, porque estamos tão isolados e impotentes" (p. 152).

Tapajós pertencia ao PCdoB e, mais especificamente, era membro da Ala Vermelha, ramificação criada em 1967, fruto de uma cisão interna ao partido. Conforme Gorender, esta organização de tendência mais radical, cujo nome se contrapunha ideologicamente à Ala Branca do mesmo partido, era constituída basicamente por estudantes e membros das Ligas Camponesas. Sua criação está associada a uma percepção de que o movimento de resistência se mantinha inerte e inoperante diante da difícil situação política do país. Tornava-se necessário construir uma nova consciência revolucionária que pudesse dar conta da expressiva demanda de hostilidade que se apresentava diante dos militantes. Seu programa não era muito diferente, na prática, do que propunha o partido. Sua meta principal era promover resistência à ditadura e o encaminhamento de um processo revolucionário pelo viés privilegiado da luta armada.

Com o objetivo de obter recursos financeiros para estruturar os focos de guerrilha, várias organizações realizaram ações armadas nos principais centros urbanos do país, como Belo Horizonte, Recife, Rio de Janeiro e São Paulo. Ainda em 1969, a Ala Vermelha iniciava um processo de autocrítica quanto à validade da luta armada e aos meios práticos utilizados para garantir o funcionamento da resistência. A prisão e a morte de alguns membros foram cruciais para novas tomadas de atitude dentro do grupo, bem como para novos desentendimentos, o que provocou a dissidência e formação de outras correntes, umas ainda ávidas pela luta armada, outras conscientes de sua impossibilidade diante do forte aparato militar do Estado.

Do conjunto de membros da Ala Vermelha presos no ano referido acima, destacase o até então cineasta e jornalista Renato Tapajós. Como já foi dito, sua prisão ocorreu em agosto de 1969, a partir de uma ação sistematicamente construída entre alguns militares e o pai de um militante de esquerda:

A história física da minha queda é mais ou menos assim: um militante que era do movimento estudantil, secundarista, aliás, por causa de outras quedas na organização, a repressão foi atrás dele. E esse militante foi abrigado num 
aparelho clandestino da organização, onde eu estava morando nessa época. Pelo que a gente sabe, ele teve contato com o pai dele, que era um oficial da reserva, que negociou com os órgãos de repressão. Tipo, eu entrego meu filho se vocês garantirem que ele não vai sofrer nada. Podem segui-lo que ele vai levar. E aí foi o que aconteceu, quer dizer, ele foi seguido, embora ele não soubesse onde era o aparelho. Mas a repressão ou seguiu, ou viu ele ser colocado dentro do carro, levado pra esse aparelho. No dia seguinte, de madrugada, o aparelho foi invadido pela polícia. Eu não estava lá. Prenderam quem estava lá, mas a gente ficou sem notícias e eu cheguei por volta de meio dia, uma hora da tarde, nesse aparelho, e fui preso na porta do aparelho (COSTA, 2009, p. 134).

A partir daí, Tapajós ficaria cinco anos preso, passando por várias seções de tortura. Durante esse período, foi transferido diversas vezes para diferentes prisões. A OBAN (Operação Bandeirantes) foi o primeiro destino do escritor. Neste lugar, segundo ele, passou pelas mais violentas formas de tortura: "Foi o período de tortura mais violento. Foram oito dias de inferno mesmo. A Operação Bandeirantes funcionava em São Paulo, na esquina da Rua Tutóia com a Abílio Soares, no quartel da polícia do Exército. E era um centro de torturas violentíssimas" (COSTA, 2009, p. 135).

Transferido deste lugar, Tapajós passou aproximadamente quatro meses preso no DOPS-SP (Departamento Oficial de Política Social de São Paulo). Em seguida, foi levado para o presídio Tiradentes. Após um ano, foi levado para a Casa de Detenção do Carandiru, onde permaneceu por seis meses. Depois retornou novamente para o Tiradentes, ficando por mais seis meses. Com a demolição deste, foi transferido para o presídio do Hipódromo, ficando lá alguns meses, antes de retornar para a Casa de Detenção do Carandiru. Foi posto em liberdade em setembro de 1974.

\section{A forma da dor: a tortura e o testemunho.}

A fim de dar uma visão mais abrangente de algumas das estratégias representacionais do romance de Tapajós, é importante compreender em que medida a fragmentação de Em câmara lenta, promovida pela repetição da cena de tortura da personagem Ela, relaciona-se com a questão do trauma, cujos estímulos estão ligados às práticas de violência da Ditadura Militar de 1964. O exame de algumas questões sobre o 
tema da tortura e seus efeitos sobre a constituição do sujeito e sobre a estrutura formal do romance contribui para o debate.

De início, vale dizer que a sucessão de cenas sempre inicia com a expressão “Como em câmara lenta". A ação se resume na tentativa das personagens Ele e Ela conduzirem de carro um companheiro até um aeroporto, de onde este pretende partir para São Paulo, levando alguns documentos. O plano fracassa quando os três são abordados por um policial. Ela o atinge com um tiro e os três fogem. No percurso, Ela é capturada e levada para uma sala de tortura. Durante todo o trajeto, os policiais lhe desferem socos, pontapés, golpes de cassetete e coronhadas de revólver. Exposta sob condições de extrema violência, a personagem é brutalmente torturada e morta:

Como em câmara lenta [...]. Passaram a vara cilíndrica do pau-de-arara entre seus braços e a curva interna dos joelhos e a levantaram, para pendurá-la no cavalete. Quando a levantaram e o peso do corpo distendeu o braço quebrado, ela deu um grito de dor, um urro animal, prolongado, gutural, desmedidamente forte. Foi o único som que emitiu durante todo o tempo. Procurava contrair o braço sadio [...], enquanto eles amarravam os terminais de vários magnetos em suas mãos, pés, seios, vagina e no ferimento do braço. Os choques incessantes faziam seu corpo tremer e se contrair [...]. O último lampejo de vontade que ainda havia nela era a decisão de não falar [...]. Furiosos, os policiais tiraramna do pau-de-arara, jogaram-na no chão. Um deles enfiou na cabeça dela a coroa-de-cristo: um anel de metal com parafusos que o faziam diminuir de diâmetro [...]. O policial começou a apertar os parafusos e a dor a atravessou [...] um dos olhos dela saltou para fora da órbita devido à pressão do crânio. Quando os ossos do crânio estalaram e afundaram, ela já havia perdido a consciência, deslizando para a morte com o cérebro esmagado lentamente (TAPAJÓS, 1979, pp. 167-172).

Contrariamente à ideia corrente que entende a tortura como um ato desumano, Maria Rita Kehl afirma que ela é uma prática essencialmente humana, uma vez que somente o homem, no extremo de sua racionalidade, é capaz de produzir mecanismos e instrumentos com o objetivo de expor o corpo de outro ser humano à dor e ao sofrimento intensos e, sobretudo, mostrar-se indiferente a isso. Conforme a autora (2004, p. 11), 


\begin{abstract}
A tortura refaz o dualismo corpo/mente, ou corpo/espírito, porque a condição do corpo entregue ao arbítrio e à crueldade do outro separa o corpo e o sujeito - no sentido do sujeito da ação, da vontade, da determinação. Sob tortura, o corpo fica tão assujeitado que é como se a "alma" - isso que no corpo pensa, simboliza, ultrapassa os limites da carne pela via das representações - ficasse separada dele. A fala que representa o sujeito deixa de lhe pertencer, uma vez que o torturador pretende arrancar de sua vítima a palavra que ele quer ouvir, e não a que o outro teria a dizer. Resta ao sujeito que se identifica com o corpo que sofre nas mãos do outro o silêncio, como última forma de domínio de si. E resta o grito involuntário, o urro de dor que o senso comum chama de "animalesco".
\end{abstract}

Segundo Corrado Bologna, a tortura perturba a relação entre corpo e estrutura psíquica da vítima, transformando-lhe em um sujeito destituído da capacidade de reconhecer a realidade e reconhecer-se nela. Em termos jurídicos, Bologna (1996, p. 344) afirma que "a tortura é uma máquina", organizada racionalmente com o objetivo de arrancar a verdade do torturado, ainda que esta verdade seja a única coisa que a tortura tenha interesse em produzir. É por esta razão que o autor afirma que o "mecanismo-base da tortura consiste [...] na redução do sujeito a objeto" (p. 345). Já na visão de Maren Viñar e Marcelo Viñar (1992, p. 73), “a tortura cria no espaço social algo como um referente de punição, cujos efeitos trágicos visam não somente à vítima, mas, através dela, o grupo social no qual provoca o medo e a paralisia”. No romance, a tortura da personagem Ela, além de produzir efeitos de compaixão no narrador e em determinado leitor, também pode ser compreendida, no contexto de autoritarismo institucionalizado, como uma demonstração do poder opressor sobre a sociedade. Através dela, instaura-se o medo, ainda que em contextos como o do Brasil a tortura continue sendo negada por muitos militares da reserva envolvidos com prisões e interrogatórios durante a ditadura.

Também é possível destacar no trecho o testemunho e a atitude de denúncia presentes de maneira visceral em todo o romance. Para Seligmann-Silva (2005), a fragmentação é uma característica central de um discurso que tem como fio condutor a necessidade de dar testemunho do que ocorreu, de maneira a fazer com que o evento nunca mais se repita, e, ao mesmo tempo, a impossibilidade de escrever a respeito, dado o aspecto devastador da experiência vivida pela testemunha. As relações estabelecidas entre linguagem e memória entram em colapso. Disso deriva uma necessidade de 
reorganização da linguagem, de sua adequação para dar conta da nova realidade, a partir de um relato constituído por elementos com forte lastro testemunhal.

Mais do que um recurso estético, esse aspecto fragmentário se relacionada com a manifestação de uma memória caracterizada pelo trauma. O episódio citado acima se apresenta como um evento que desestabiliza as relações do narrador com a realidade à sua volta. A história principal é constantemente interrompida pela lembrança do acidente traumático, que somente se concretiza em sua totalidade após várias tentativas de elaboração. Essa dificuldade de narrar o evento também está associada ao compromisso ético do narrador em dar testemunho de sua experiência e ao mesmo tempo precisar esquecê-la: "Porque o meu compromisso é com os mortos e com os que vão morrer. E mesmo errado esse é o único compromisso que existe e se eu parar, recuar ou sair do país eu vou ficar o tempo todo vendo os rostos como acusações daqueles que acreditaram" (TAPAJÓS, 1979, p. 160).

Para o narrador, é preferível passar pela dolorosa experiência de ter que contar a história traumática e continuar a lutar como forma de honrar os mortos, do que se calar, pois, se assim o fizesse, continuaria atormentado pelas lembranças e imagens fantasmagóricas dos seus companheiros. Os elementos de seu relato com teor testemunhal deveriam funcionar como um mecanismo de libertação, de denúncia dos atos de tortura que levaram à morte de pessoas afetivamente ligadas a ele e, sobretudo, de recuperação e registro da memória coletiva do país como elemento necessário e central na luta contra o esquecimento pleno. Mas é evidente que essa libertação não ocorre plenamente no romance. O luto não se realiza e o narrador passa a viver em estado melancólico (FREUD, 2010). Sobre esse aspecto, para alcançar o nível de fabulação no romance, Tapajós parece estar alinhado a traços sintomáticos da estética do choque que fragmenta a forma a partir de elementos próprios da narrativa romanesca e da narrativa cinematográfica. A estética do choque reorganiza o modo de perceber e lidar com a realidade, ativando o estado de alerta diante da ameaça de catástrofe (ADORNO, 1988).

Quando, ao tratar da memória coletiva no pensamento de Maurice Halbwachs, Paul Ricœur (2007, p. 131) afirma que “o testemunho não é considerado enquanto proferido por alguém para ser colhido por outro, mas enquanto recebido por mim de outro a título de informação sobre o passado", o autor se refere ao significado social do testemunho, e não enquanto atividade meramente individual. Porém, por ser objeto 
primeiramente constituído na memória individual e somente depois tornado coletivo pela situação de pertencimento de um sujeito a um grupo, o testemunho é construído a partir de um trabalho seletivo da memória. Para Ricœur (2007, p. 455), “assim como é impossível lembrar-se de tudo, é impossível narrar tudo".

Seguindo na esteira desse autor, é possível afirmar que o romance Em câmara lenta está inscrito em um movimento contrário à dimensão da memória manipulada que favorece o esquecimento. Contra o privilégio de diversos escritos sobre o recente passado brasileiro, singularizados pela história oficial como referências inquestionáveis, o romance de Tapajós se coloca como objeto artístico que revela a dor da derrota, ao mesmo tempo em que denuncia a violência por meio da voz de um militante legítimo da resistência.

Em importante estudo, Jeanne Marie Gagnebin propõe uma ampliação do conceito de testemunha ao analisar uma cena do livro É isto um homem?, de Primo Levi, publicado pela primeira vez em 1947. Na cena, Levi conta a respeito de um pesadelo que tem repetidas vezes dentro do campo de concentração de Auschwitz. Ele está em casa, na mesa de jantar, reunido com sua família, contando as dificuldades de sobrevivência no campo. Depois de algum tempo, percebe que as pessoas ali reunidas são indiferentes às suas histórias. Sua irmã, então, olha para ele, "levanta, vai embora em silêncio" (LEVI, 1988, p. 60). Para Gagnebin, esta cena tem efeito afirmativo sobre o conceito de testemunha, na medida em que, ao contrário da irmã de Levi, aquele que se permite ouvir o que o outro (a vítima) tem a dizer se torna porta-voz daquela experiência de dor e sofrimento. Essa proposição implica, portanto, uma tomada de atitude de empatia com a vítima, uma capacidade de ouvir e o compromisso de levar adiante o relato, como objeto de reflexão crítica sobre o passado. A autora comenta que "somente essa tomada reflexiva do passado pode nos ajudar a não repeti-lo infinitamente, mas a ousar a esboçar uma outra história, a inventar o presente" (GAGNEBIN, 2006, p. 57).

Em certa altura de É isto um homem?, Primo Levi traz à luz uma ponderação sobre a validade da memória de Auschwitz: "Poderíamos, então, perguntar-nos se vale mesmo a pena, se convém que de tal situação humana reste alguma memória”. Em resposta a esta indagação, o autor afirma:

A esta pergunta, tenho a convicção de poder responder que sim. Estamos convencidos de que nenhuma experiência humana é vazia de conteúdo, de que 
todas merecem ser analisadas; de que se podem extrair valores fundamentais (ainda que nem sempre positivos) desse mundo particular que estamos descrevendo (LEVI, 1988, p. 88).

Em situações de ameaça como a apresentada no romance de Tapajós, a necessidade de sobreviver justifica-se particularmente pelo compromisso com aqueles que não podem mais ser testemunhas de si mesmos. Seguir adiante, ainda que de modo precário, significa dar o último grito de dor que deverá ecoar no tempo, em uma perspectiva de rememoração, no sentido benjaminiano do termo.

Segundo Giorgio Agamben (2008), há duas categorias originárias do latim para representar a figura de uma testemunha. A primeira delas corresponde à testis, isto é, uma terceira pessoa dentro de um julgamento que deverá dar sua versão sobre um acontecimento que apenas viu, sem nenhum envolvimento direto. A segunda categoria diz respeito à superstes. Esta, por sua vez, implica a participação direta de alguém em um evento e a produção de seu relato a respeito dele. Tomar essas categorias como parâmetros conceituais para analisar as atitudes do narrador de Em câmara lenta, procurando compreender seu discurso na linha do testemunho, pode ser producente, embora seja necessário levar em conta algumas implicações. Primeiramente, deve-se considerar que o narrador de Tapajós não é testis, porque não presenciou a tortura da personagem Ela. Sua versão deriva do relato de um primo seu. Depois, não pode ser superstes, porque não foi vítima direta da tortura. Nesse sentido, cabe uma pergunta: o que pode caracterizar Em câmara lenta como uma narrativa testemunhal?

Uma das chaves para tal questão pode estar contida em uma fala de Primo Levi citada por Agamben: "seu testemunho se dá por meio de minhas palavras" (LEVI, apud AGAMBEN, 2008, p. 48). O referente aqui é Hurbinek, uma criança morta depois de ser libertada de Auschwitz, e que, por conta da idade, ainda não era capaz de verbalizar claramente suas palavras. Diante dessa incapacidade, Levi incorpora seu sofrimento, assumindo, por processo de empatia, sua dor e sua voz. Analogamente, a personagem de Tapajós é torturada e morta, mas nem por isso deixa de ser testemunha de sua própria aniquilação. O procedimento narrativo usado no romance transfere para o narrador a possibilidade de testemunhar por aquela que teve a fala silenciada. Nessa linha de interpretação, é válido afirmar que o romance é constituído tanto pelo relato testemunhal 
do narrador, que seria testis, quanto pelo relato da personagem feminina, superstes, ambos emitidos através de uma única voz.

Agamben também comenta que, em grego, a categoria "testemunha" recebe a denominação martis, que em português quer dizer mártir. O autor faz uma observação importante ao afirmar que "o que aconteceu nos campos [de concentração nazista] pouco tem que ver com o martírio" (AGAMBEN, 2008, p. 35). Ao mesmo tempo em que nega essa relação entre um mártir e uma vítima de campo de concentração, o autor lembra que o termo martis deriva da palavra "recordar". Ser um mártir, nesse sentido, significa expor o próprio corpo e a própria mente a alguma forma de sofrimento, desde que esta exposição sirva para recordar, através do testemunho do corpo supliciado, uma convicção. Portanto, esse testemunho não se realiza sem o trabalho da memória. Produto desta última, o testemunho não poderia se constituir a não ser através da lacuna, da dissociação discursiva (principalmente quando se trata de uma memória traumática) e do movimento descontínuo do relato. Nas palavras de Agamben (2008, p. 43), "o testemunho vale essencialmente por aquilo que nele falta". O que falta no testemunho é a parte indescritível da experiência, é o impossível de ser apreendido e simbolizado em palavras. O que em parte caracteriza o discurso testemunhal, então, é a fissura da linguagem, a sua desarticulação de forma e conteúdo, um certo "balbuciar desarticulado" de "uma linguagem mutilada e obscura" (p. 46).

Diante disso, o que é Em câmara lenta senão a construção literária de uma memória cindida pela violência? O episódio do garoto Hurbinek serve como ilustração dessa estrutura fragmentária e de difícil apreensão do discurso testemunhal. Hurbinek tenta pronunciar uma palavra que soa incompreensível aos ouvidos das pessoas ao seu redor. Levi (1988, p. 47) transcreve como “mass-klo ou matisklo". Algo certamente enigmático e quase impossível de ser decifrado, como o urro animalesco emitido pela personagem Ela.

Há um desafio imposto à crítica literária que se defronta com obras como a de Tapajós, cujas formas tradicionais de composição são suspensas e dão lugar a representações de experiências traumáticas, produzindo desconforto e choque a quem lê. Malcolm Silverman (2000) chama de "excruciantes" as cenas de tortura narradas no livro do escritor paraense, termo que estabelece uma profunda sintonia com a categoria do sublime, aquilo que é impossível de ser nomeado ou simbolicamente representado. 
Assim, Em câmara lenta reivindica o status de arte revolucionária ao propor resistência à opressão, ao se comportar como "arte posta a serviço da revolução" (CAMUS, 2008, p. 292). De acordo com Camus, o romance nasceu juntamente com a necessidade de o homem se revoltar, seja com o passado aniquilador, seja com o presente que insiste em perpetrar modelos de estruturas sociais tradicionais, ou mesmo com a própria maneira de representar esteticamente a sociedade. Por outro lado, o romance que traz em seu bojo o espírito de revolta acaba por estabelecer um pacto contra o esquecimento. A arte do romance "alia-se à beleza do mundo ou dos seres humanos contra as forças da morte e do esquecimento" (p. 307).

O romance de Tapajós ainda permite vislumbrar o lado negativo da luta revolucionária. A autocrítica que realiza em torno dos meios utilizados pela esquerda para combater a ditadura traz à tona um conjunto de reflexões sobre a legitimidade e a eficiência dos mecanismos de resistência. A lembrança da tortura e da morte da personagem Ela ainda lateja na memória do narrador. Ele pretende julgar o valor de suas ações e se reconhece limitado para tal atitude: "a sensação de perda é física, como se faltasse a laringe e o esôfago" (TAPAJÓS, 1979, p. 13).

É nesse sentido que a obra de Renato Tapajós pode ser compreendida como um objeto artístico que elabora em sua estrutura formal os problemas desencadeados pela violência de Estado. Para Kehl (2004, p. 16), “a dor é também objeto de arte, é recurso do artista, que inventa objetos que representam seu mal-estar e inscrevem seu sofrimento no campo do simbólico, no laço com os outros". A composição fragmentária do romance, narrado a partir de um ponto de vista traumatizado, permite considerar, na perspectiva de Adorno (1988), que o choque não apenas redimensiona critérios de gosto estético, como também reelabora as possibilidades de se compreender as contradições sociais da vida moderna. Para Marcia Tiburi (2004, p. 163), “a arte contemporânea é [...] resquício de aniquilações sob forma de representação, herança e espólio que traz à presença a contradição - que ela mesma é - e o horror”.

\section{Considerações finais}

A câmara lenta é uma técnica da narrativa fílmica utilizada para tornar possível a percepção de movimentos rápidos e, de acordo com Martin, “inapreensíveis a olho nu”. 
Além disso, ainda segundo esse autor, "cenas de morte violenta" são "frequentemente mostradas" a partir desse recurso que também pode sugerir uma "excepcional intensidade do momento" (MARTIN, 2007, p. 215), feliz ou angustiante. A narração da cena de tortura em questão, constituída por meio da montagem, aponta para as precárias relações entre a necessidade de narrar e a dolorosa tarefa de recuperação do passado traumático, dada a dificuldade de elaboração. Assim, a cena não apenas se constitui a partir do choque, mas provoca esse choque e um profundo "sentimento de realidade" no leitor (MARTIN, 2007, p. 22).

Certamente o contexto que envolve o processo de prisão de Renato Tapajós, os meios utilizados para escrever sem ser notado, o sofrimento causado pela tortura, a lembrança da crueldade exercida sobre sua cunhada, tudo isso exerceu grande impacto no procedimento literário adotado para escrever Em câmara lenta. Por esta razão, é necessário ressaltar que o engajamento político de Tapajós não abdica de um trabalho cuidadoso com a linguagem. Para ser compreendida de um ponto de vista engajado, a obra literária não deve prescindir de uma linguagem e uma forma que lhe qualificam como tal. Não é por falar em nome das massas que o escritor precisará abdicar de um fazer artístico com qualidade estética. Seu engajamento reside justamente onde a linguagem não se faz gratuita e não se reduz à mera informação ou a um simples canal de veiculação de uma ideologia. Sua arma não é a foice nem o microfone diante da multidão, mas, sim, a palavra, e esta poeticamente construída. Em câmara lenta vincula-se a esta concepção de engajamento.

A dor da personagem Ela não é expressa somente pelo angustiante testemunho do narrador, mas está nevralgicamente constituída no plano formal da narrativa. Ela resistiu à dor ao silenciar-se diante do suplício. Seu silêncio possui uma dupla interpretação. Por um lado, está associado ao caráter aniquilador da tortura, cujo objetivo principal é "provocar a explosão das estruturas arcaicas constitutivas do sujeito, isto é, destruir a articulação primária entre o corpo e a linguagem" (VIÑAR; VIÑAR, 1992, p. 73). Por outro lado, representa a atitude de resistência e afirmação da vida de quem a sacrificou em nome de um ideal. Para Kehl (2004, p. 16), “É um homem [ser humano] esse corpo capaz de silenciar para garantir seu último grão de liberdade diante da tortura". Na visão de Bologna, o silêncio do supliciado (torturado) é a máxima expressão da impossibilidade que o homem tem de reduzir a dor em matéria verbalizada: "Não será já a morte do corpo 
orvalhado pelo sangue a iluminar a alma na salvação, mas sim a auréola do silêncio, arma aguçada da Vítima” (1996, p. 359). Calar-se diante da iminente possibilidade de morte, mesmo sabendo que, uma vez rompido o silêncio, sua vida poderia ser poupada, sugere uma tomada de decisão eticamente coerente com uma das propostas do livro de Tapajós: a defesa da necessidade de resistir, a todo custo, ao poder opressor.

Ao apresentar o conceito de tortura, Bologna traz para o centro da discussão a ideia de martírio. Categoria ligada à ideologia messiânica do pensamento cristão, o martírio de um indivíduo é entendido como garantia da salvação de uma coletividade. A exposição do corpo e da mente à dor extrema purifica não apenas o mártir, mas também todos aqueles que se identificam com o indivíduo supliciado. Segundo o autor:

\footnotetext{
De fato, o martírio é, antes de mais, um testemunho, martyrion: o mártir é testis, é o Terceiro chamado para sancionar a Verdade com o silêncio ou com a confissão (que é um ato de fé). O mártir (martyr, martys) é assim uma testemunha; o seu sofrimento representa, de um modo memorável, a gloriosa passio do Redentor inocente, e cada martírio é um testemunho, uma repetição, uma imagem reflexa daquele primeiro martírio fundador: é aquele martírio [...] se aos martyres também se pode chamar testes, é porque aceitaram e sofreram o martírio para serem testemunhas de Cristo (BOLOGNA, 1996, p. 357).
}

Reservadas as vinculações religiosas que esta fala recupera, no caso do romance Em câmara lenta, apenas a primeira forma de testemunho apresentada por Bologna pode ser levada em consideração. Por meio do silêncio, a personagem Ela reafirma o compromisso moral com a resistência. Seu sofrimento somente pode ser observado pelos torturadores por meio da aniquilação do corpo, que se encontra danificado por ferimentos e lavado em sangue. A ausência da palavra sugere a completa adesão da personagem à necessidade de resistir até a morte.

Tem-se, assim, uma noção bastante provocadora do significado de testemunho. $\mathrm{O}$ sujeito que, uma vez posto sob condições de tortura, silencia-se em nome da integridade de um determinado corpo social e, por esta atitude, paga com a própria vida, também é uma testemunha. Nesse sentido, ratificamos a ideia de que não apenas o narrador de Em câmara lenta é uma testemunha, mas a própria personagem Ela. E mesmo diante da experiência de sofrimento, o ato de testemunhar carrega em si alguma forma de prazer associada à libertação da mente, outrora amputada do corpo pela tortura. Bernardo de 
Claraval, em uma citação feita por Bologna (1996, p. 357), afirma que “o mártir mantémse exultante e triunfante, mesmo com o corpo todo martirizado; e com o flanco aberto pela espada, observa não só com força de alma mas até com felicidade o sangue sagrado que jorra fervescente da sua carne".

\section{REFERÊNCIAS}

ADORNO, Theodor W. Teoria estética. Lisboa: Martins Fontes, 1988.

AGAMBEN, Giorgio. A testemunha. In: . O que resta de Auschwitz: o arquivo e a testemunha (Homo Sacer III). São Paulo: Boitempo, 2008 (Estado de sítio).

BASTOS, Alcmeno. A história foi assim: o romance político brasileiro dos anos 70/80. Rio de Janeiro: Caetés, 2000.

BENJAMIN, Walter. Origem do drama barroco alemão. São Paulo: Brasiliense, 1984.

BOLOGNA, Corrado. Tortura. Enciclopédia Einaudi. Vol. 22. Lisboa: Imprensa Nacional-Casa da Moeda, 1996, p. 344.

BOSI, Alfredo. Narrativa e resistência. In: Literatura e resistência. São Paulo: Companhia das Letras, 2002, p. 118-135.

CAMUS, Albert. O homem revoltado. Rio de Janeiro: Record, 2008.

CORTÁZAR, Júlio. La teoria del túnel. Disponível em: < http://www.ciudadseva.com/textos/teoria/opin/cortaz7.htm>. Acesso em: 26 fev. 2007. COSTA, Carlos Augusto Carneiro. Militância política, pensamento e literatura: Renato Tapajós e o regime militar no Brasil (Entrevista). Literatura e Autoritarismo. Dossiê "Cultura Brasileira Moderna e Contemporânea”. Dezembro de 2009, p. 129. Disponível em: 〈http://coralx.ufsm.br/grpesqla/revista/dossie02/RevLitAut_art12.pdf >. Acesso em: 10 jan. 2010.

FREUD, Sigmund. Luto e melancolia (1917 [1915]). In: Introdução ao narcisismo: ensaios de metapsicologia e outros textos (1914-1916). São Paulo: Companhia das Letras, 2010, pp. 170-194. (Obras completas, volume 12).

GAGNEBIN, Jeanne Marie. Lembrar escrever esquecer. São Paulo: Ed. 34, 2006.

GORENDER, Jacob. Combate nas trevas. São Paulo: Ática, 1990.

KEHL, Maria Rita. Três perguntas sobre o corpo torturado. In: KEIL, Ivete; TIBURI, Marcia (orgs.). O corpo torturado. Porto Alegre: Escritos Editora, 2004, pp. 9-19.

LEVI, Primo. É isto um homem? Rio de Janeiro: Rocco, 1988. 
MARTIN, Marcel. A linguagem cinematográfica. São Paulo: Brasiliense, 2007.

RICEEUR, Paul. A memória, a história, o esquecimento. Campinas-SP: Ed. da Unicamp, 2007.

RIDENTI, Marcelo. Em busca do povo brasileiro: artistas da revolução, do CPC à era da TV. Rio de Janeiro: Record, 2000.

RIDENTI, Marcelo. Brasilidade revolucionária como estrutura de sentimento: os anos rebeldes e sua herança. In: Brasilidade revolucionária: um século de cultura e política. São Paulo: Editora UNESP, 2010.

ROSENFELD, Anatol. Reflexões sobre o romance moderno. In: Texto/contexto: ensaios. São Paulo: Perspectiva; Brasília: INL, 1973, pp. 75-97.

SELIGMANN-SILVA, Márcio. O local da diferença: ensaios sobre memória, arte, literatura e tradução. São Paulo: Ed. 34, 2005.

SILVERMAN, Malcolm. Protesto e o novo romance brasileiro. Rio de Janeiro: Civilização Brasileira, 2000.

TAPAJÓS, Renato. Em câmara lenta. $2^{a}$ ed. São Paulo: Alfa-Ômega, 1979.

TIBURI, Marcia. Cinzas. In: KEIL, Ivete; TIBURI, Marcia (orgs.). O corpo torturado. Porto Alegre: Escritos Editora, 2004.

VIÑAR, Maren; VIÑAR, Marcelo. Exílio e tortura. São Paulo: Escuta, 1992. 